\title{
Duruş Noktası: Fotoğrafta Karar Anı ve Yorum
}

\section{The Standpoint: Decisive Moment and Interpretation in Photography}

\section{Ardan Ergüven}

Doç., Marmara Üniversitesi, Güzel Sanatlar Fakültesi, Grafik Bölümü

email: ardanerguven@gmail.com iDORCID ID: https:/orcid.org/0000-0001-9331-3038

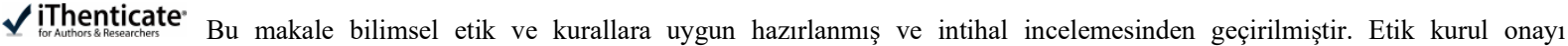
gerektirmemektedir.
\end{abstract}

Atıf (APA 6)/To cite this article

Ergüven, A. (2021). Duruş noktası: Fotoğrafta karar anı ve yorum. Atatürk Üniversitesi Güzel Sanatlar Enstitüsü Dergisi, 27(46), 59-66. https://doi.org/10.35247/ataunigsed.853927

Makale Gönderim Tarihi/Received: 04/12/2020

Makale Kabul Tarihi/Accepted: 15/01/2021

Makale Yayın Tarihi/Published: 29/03/202

Research Article/Araştırma Makalesi

Öz

Başarılı fotoğrafin gerekçesi olarak kabul edilen doğru "karar anı" (H. Cartier Bresson), aslında sadece doğru zamanla değil, konumla da ilgilidir. Bir başka deyişle duruş yerinin yanı sıra bakıs hattı ve açısıyla da bütünleşmediği sürece, "karar anı" belirleyici olmaktan çıkar. Öte yandan kalıcı olmaya aday her fotoğrafa bu koșulları aşan bir bașka șey daha eşlik eder: talih etmeni. Talih, fotoğrafın hammaddesi olan 1 şığın zaman ile gireceği iş birliğinin gizemli konuğudur. $\mathrm{Bu}$ çalışma "duruş noktası" ile kesișen "karar anı" kavramını, farklı zamanlarda ve yerlerde çekilmiş iki fotoğrafı yorumlayarak ele almaktadır. Bu araştırma farlı örnekler üzerinden bir karşılaştırma yaparak bakış hattının fotoğrafın anlamını ve dolayısıyla yorumu nasıl etkilediğini açıklamaktır.

Anahtar kelimeler: Duruş Noktası, Karar Anı, Dipyüzey, Perspektif, Fotoğraf

\begin{abstract}
The right "decisive moment" (H. Cartier-Bresson), which is accepted as the justification for successful photography, is not only about the right time but also the location. In other words, as long as it does not integrate with the point of view as well as the point of view, the "decisive moment" ceases to be decisive. On the other hand, another thing that exceeds these conditions accompanies every photograph that is likely to be permanent: the factor of luck. Fortune is the mysterious guest of the collaboration that light, the raw material of photography, will enter with time. This study discusses the concept of "decisive moment" that intersects with "standpoint" by interpreting two photographs taken at different times and places. This research aims to explain how the line of sight affects the meaning of the photograph and therefore the interpretation by making a comparison through different examples.
\end{abstract}

Keywords: Standpoint, Decisive Moment, Bottom Surface, Perspective, Photograph

\section{Giriş}

Fotoğraflamak için seçtiğimiz görüntüye hangi seviyeden baktığımız anlamı belirleyen konuların başında gelmektedir. Duruş noktası, fotoğrafladığımız görüntüyle kurduğumuz ilişkiyi deşifre ederken aynı zamanda izleyiciye aktarılan öyküye ve duygulara yön verir. Diğer taraftan bir görüntüye hangi açıdan bakacağımız her zaman kendi insiyatifimizde değildir. Fotoğrafçı ne zaman bir engelle karşılaşsa, konu üzerinde yoğunlaşmış belli bir bakış açısına sahip olduğunu ve bundan başka seçeneklerinin olduğunun farkına varır. Buradaki mesele mükemmel bakış açısına sahip olmak değil, olabildiğince çok bakış açısı geliştirmektir. Diğer taraftan fotoğraf, gerçekçilikle olan sıkı bağını, kaydedilenin arkasında durmaya borçludur. Belki de bu yüzden, bir fotoğrafı görmek, kolayca algılayabilmenin ötesinde, bir başka beklenti ile hesaplaşmayı şart koşar; ve bu da, fotoğrafla ilgili düzenleme bağlamında, klasik ne ve nasıl sorularından farklı olarak, bizi bir kez daha gördüğümüzü, yani fotoğrafta kaydedilmiş olanı görmeye davet eder. Görüntünün müdahaleye kapalı mekanik kaydı, algıyı zora koştuğu andan itibaren, fotoğrafta gördüğümüzden çıkıp, fotoğrafın kendisine geçme yolunda ilk adım atılmış demektir. Bir başka deyişle, görmenin ilgi odağına kaydedilen değil, görünenin baskısından kurtulmaya hazır kayıt'ın kendisi girer. Buna göre, gündelik yaşamda kolayca algılayabildiğimiz bir şeyin fotoğraftaki karşılığını tanımakta zorlanmaya başlayınca, sorgulanmayı bekleyen şey de, kendiliğinden ve büyük ölçüde yerini sentaktik kaygının gündemde olduğu düzenlemeye bırakır.

\section{Yöntem}

$\mathrm{Bu}$ araştırma, betimsel modele dayalı nitel bir araştırmadır. Çalışmada kavramsal çerçeveyi belirlemek için literatür taraması yapılmıştır. Bununla beraber fotoğraf sanatının yanı sıra görsel sanatlar ve edebiyat gibi sosyal bilimlerin diğer alan literatürlerinden faydalanılmıştır. Araştırma, fotoğrafa özgü estetik unsurların oluşum sürecini konu alırken, kaydedilen görüntü ile birlikte ortaya çıkan görsel anlamı deşifre etmekte, aynı zamanda "Duruş Noktası" ve "Karar Anı" kavramları üzerinden fotoğraf kompozisyonunun olușumunu açıklamaktadır. Bu kapsamda algıyı oluşturan konum ve konu arasındaki ilişki, bir bütün olarak ele alınmıştır. Fotoğrafçının farklı durumlar arasından nasıl seçim yaptığı ve gerçekliğin derinliği içinde doğru durumu nasıl saptadığı değerlendirilmiştir. Çalışmada farklı zamanlarda ve yerlerde çekilen fotoğraflar incelenmiş, aynı zamanda birinci el kaynaklardan elde edilen bilgiler ile görsel ve kavramsal bir analiz yapılmıştır. 


\section{Bulgular}

Araştırma sonucunda duruş noktasının göre fotoğraf karesine dahil edilen görüntülerin, seyircinin konumunu ve öznenin anlamını etkilediği görülmüştür. Ele alınan örnekler, aynı zamanda duruş noktasıyla birlikte değişen arka planın gerçeklik algısını değiştirdiği ve bir anlamda sanat eserlerine özgü bir anlatım ile kurgusallaştırdığını gösterir. Özellikle tepeden bakış ile bir tür altlığa düşen dipyüzeyin, iki boyutlu anlatım olanaklarını devre dışı bırakarak soyutlayıcı bir etkisi olduğu ortaya çıkmaktadır.

\subsection{Karar Anı}

Robert Capa'nın 17-18 Temmuz 1943 tarihleri arasında Agrigento, Sicilya'da çektiği bir fotoğrafta eski evlerin dizili olduğu dar bir sokakta, yıkıntılar arasında yürümeye çalışan yaşlı bir kadın dikkatimizi çekiyor. Elinde taşıdığ beyaz pakette ne olduğunu bilmiyoruz. Tahmin etmek güç değil: Fiziksel görüntüsünden ve giyiminden anladığımız kadarıyla yıkılan evin bir sakini değil. Oradan geçerken, Capa'nın uygun bir konuma geldiğinde konuya dahil etiği, sokağın ve evlerin boyutunu anlamamızı sağlayan bir figür sadece. Ancak elinde tuttuğu paket bir yere ulaşmaya çalıştığını gösteriyor. Fotoğrafın hemen altına düşülen not bu düşüncemizi doğrulamakta: "Kurtarılan fakat ağır hasara uğrayan şehirde hayat devam ediyor.” Aynı figürün daha yakından çekilmiş bir fotoğrafı bu düşüncemizi tasdikliyor: Fotoğrafçı ile göz göze gelmekten kaçınan kadının belli ki anlatmak ya da göstermek istediği bir derdi yok. O sadece Capa ile aynı zaman dilimi içinde yolu kesişen bir figüran. Fakat Capa'nın yakaladığı sahnede sokağın görüntüsü, arka plandaki perspektifin de etkisiyle daha çok dikkat çekiyor. Sabah saatlerinde çekildiğini düşündüğümüz bir fotoğrafta bir kargaşa veya endişe yok. Daha da ötesi İtalyan kasabalarına özgü mimari ile birlikte sokak resimlerinde görmeye alışık olduğumuz arka plan, ön plandaki molazların dramatik görüntüsüne gölge düşürüyor. Belli ki bu yıkıntılar olmasa bir Atget fotoğrafı ile karşılaşma olasılığımız bile var. Capa da bunun farkına varmış olmalı ki aynı kadını yıkıntıların daha ön planda olduğu bir açıdan tekrar fotoğraflamış. Ama bu sefer de güneşli hava belki de istediği etkiyi yakalamasına engel oluyor. Capa'nın denemeleri doğru zamanda, doğru yerde olsa bile konuya uygun bir duruş noktası aradığını gösteriyor (Görsel 1 ve 2).

\section{Görsel 1}

Agrigento Harabeleri Arasında Yaşlı Kadın

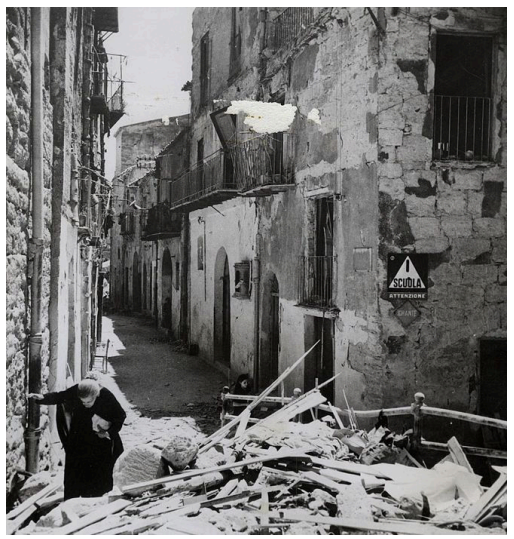

(Capa, 1943a).

\section{Görsel 2}

Savaş Insanlık Dışıdır

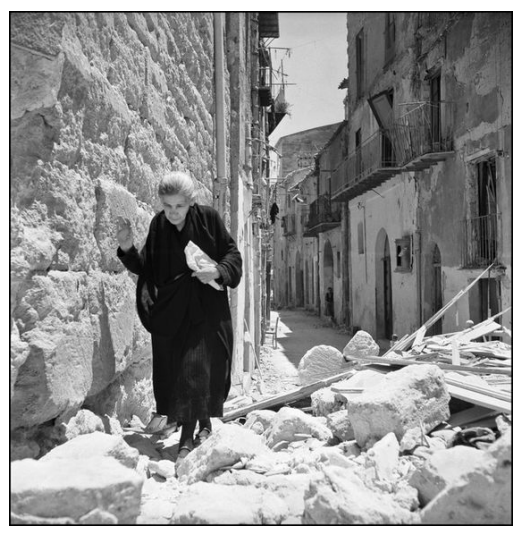

(Capa, 1943b). 
Duruş noktasının konu anlatımını nasıl etkilediğini gösteren bir başka fotoğrafa bakalım. Bağdat'ta çok sayıda kişinin ölümüyle noktalanan bir patlamanın fotoğrafı, bu konuda bize epey yardımcı oluyor. Her zaman olduğu gibi, bu örnekte yine bağlı olduğu ajans için çalışan adsız bir foto muhabirinin belgesel kaydını görüyoruz. Ama patlamanın şiddetini belgeleyen kayıt, sanki izleyiciyi fotoğrafta gördüğünden çok, bu sürece aracı olan fotoğrafın kendisiyle hesaplaşmaya davet ediyor. Bir fotoğrafta, anlık algılamanın ötesinde, ayrıca deşifre etmek zorunda kaldığımız her görüntü, giderek yanılsamanın tutsağı olmanın ötesinde, en azından fotoğraf estetiğine giden yolun gizli yapıtaşlarını içerir (Görsel 3).

$\mathrm{Bu}$ fotoğrafa dikkatli bakınca, önce duruş noktasıyla ilgili belirsizliğe tanık oluyoruz. Dahası, bu belirsizliğin kökeninde, sanki fotoğrafı çekenden çok izleyici yer alıyor. Aslında kaydedilen görüntüye ilişkin her duruş noktası, izleyicinin mecburen kabullenmek zorunda kaldığ 1 yerdir. Buna göre, romandan resme, tiyatrodan filme kadar sanatın tüm dallarında, bir şeyi hep belli bir yerden bakarak görürüz. Öte yandan, belli bir yerden bakıyor olmak, söz dilinde anlatıma bağlı kalıp, neyi, nasıl ve ne kadar göreceğimizi bize bırakırken, kamera ile mekanik kayıt söz konusu olduğunda değişime uğrayarak, bir tür oldubittiyle gözümüze el koyar. Romanda canlandırma amacıyla görmeye çalıștığımız şey öznel bilinç ve alg1 niteliğinin katkısıyla gerçekleşirken, fotoğrafta gösterilen'in tek taraflı baskın yapısından dolayı, bu nerdeyse kendiliğinden gerçekleşir. Mekanik yoldan kaydedilmiş bir şeyi görmek için, dış dünyadaki karşılığını tanıyor olmak yeterlidir. Ne var ki, bu örnekte kaydına talip olunan görüntü ile duruş noktası âdeta yarış halinde; foto muhabiri, sanki “bulunduğu yerde"yi belgelemek üzere deklanşöre basmış.

\section{Görsel 3}

Bağdat'ta Patlama

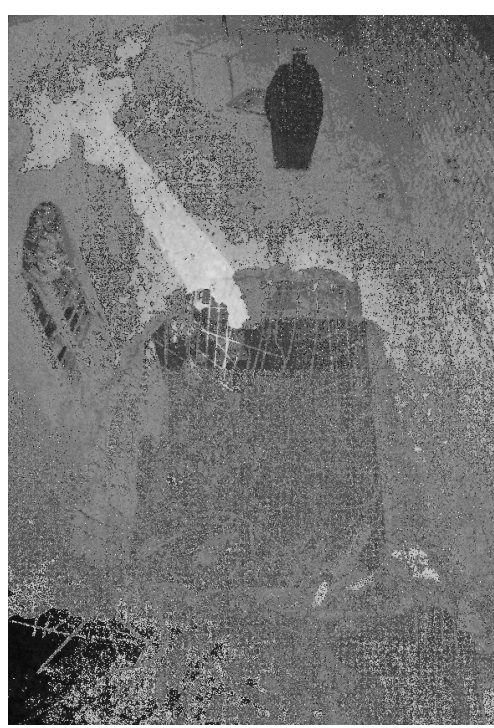

(Reuters Photographer, 2004).

Zemin ile dipyüzeyin birbirine karıştığı bu örnekte kameranın duruş noktasıyla ilgili soruyu yanıtlamakta zorlanıyoruz. Özellikle önde delik deşik olmuş yerin duvar mı yoksa yol mu olduğu konusunda izleyiciyi epey zora koşuyor. Buna göre, üstte duran adam ile soldaki pencere, burasının yol olduğunu açıkça kanıtladığ 1 zaman bile, söz konusu bocalama hâlâ devam ediyor. Öyle ki, gözümüz kamera ile kaydedilmiş olana burada son ana kadar direnmeye kararlı; objektifin duruş noktası, mekanik kaydın güvencesiyle, bizi gördüğümüze değil gerçeğe inanmak zorunda bırakır-ama bu gerçek de hiç şüphe yok ki, yine kamera sayesinde kendini doğruluyor. Sonuçta, gözümüze rağmen ve ister istemez, fotoğrafa teslim oluruz.

Aslında ayrıntıya geçmeden kabaca algılamaya çalıştığımız zaman, bu fotoğrafı Max Ernst veya René Magritte imzalı bir resimle birbirine karıştırmak pekâlâ mümkündür. Ancak öznel müdahaleden bağımsız bir mekanik kayıtta, hayal gücüne havale edilmiş bir gerçeküstü düzenlemenin kaydı söz konusu olamayacağ 1 için, burada görsel mantığa uygunluğu dikkate almak zorunda kalıyoruz; ve tam da bu noktada, sanki görünmeyen bir soru işareti her şeye damgasını vuruyor (Duane, 1976, s. 126).

Önce mekândan başlayalım: Pencere ve duvar ile kuşatılmış bu yer çatı olmadığına göre, büyük bir olasılıkla avlu veya teras; ama bu kanıtlansa bile sonuçta açıklayıcı olmuyor; çünkü başka bir şeyin de söz konusu olabileceği duygusu bizi devamlı kararsızlığa sürüklüyor. Bu aşamada fotoğrafta gördügüüüzü bir yana bırakıp, fotoğrafa geçmek kaçınılmaz olmaktadır. 
Fotoğraf terminolojisine "karar ânı" olarak geçen doğru zamanlama, bu alandaki başarıyı tanımlarken en fazla gündeme gelen ölçütlerden biridir. Ne var ki, burada başarıyı belirleyen ölçütün sacayağını anımsadığımız zaman, karar ânının duruş noktasına ilaveten, bakış hattı ve açısı ile tamamlandığını görmekte gecikmeyiz. Gerçi doğru zamanlamanın buradaki rolü, hiç kuşkusuz genelde taşıyıcı payda olarak çoğu defa ön plandadır; ama aynen bu örnekte karşılaştığımız gibi, zaman ile yarışın söz konusu olmadığı durumda, duruş noktası ile bakış hattı ve açısı kendiliğinden ağırlık kazanarak, sonuçta fotoğraf estetiğine ilişkin bir değerlendirme ölçütüne dönüşür (Cartier Bresson, 2006, s. 16).

John Szarkowski’ye göre fotoğraf bir görsel editörlük sistemidir. Temelde, doğru yerde ve doğru zamanda bulunarak konuyu bir bakış açısıyla çerçeveleme sorunudur. Satranç oynamak veya yazmak gibi olasılıklardan birini seçmektir ama fotoğrafta olasılıkların sayısı sınırsızdır. Fotoğrafçının rasyonel olanla başa çıkması çok zordur. Bu nedenle fotoğrafçılar doğru bakışı bulmak için belirsizlik içinde, huzursuzca dolaşırlar ve potansiyel olarak ilginç birçok kaydı görmezden gelerek başka bir şey ararlar (Szarkowski, 2002, s. 8).

$\mathrm{Bu}$ vesileyle, her fırsatta gündelik yaşamdan kaydedilmiş sıradan fotoğrafları anımsamaya çalışalım: Bunların çoğu, hatta hemen hepsinde karar ânı, farkına varmadan zamana öylesine yapılmış yetersiz müdahalenin eseridir. Buna göre, "Tam öyle dur!" ya da "Başını eğme!” vb. komutlar, her ne kadar öncelikle duruş noktası veya bakış açısıyla ilgili gibi görünse de, aslında zamana ilişkin bir kaygıdan kaynaklanır. Kamera karşısındaki bir kişiye "Tam istediğim şekildesin, kımıldama!” demek, özünde kairos, daha doğrusu saatin tik taklarıyla yarışa çıkmaktır. Şipşak çekilmiş fotoğraflar ise, ayrıca aramaya gerek kalmadan hazır bulunmuş zamanın armağanıdır; ama bu defa da duruş noktası ile bakış açısının ne ölçüde isabetli olduğu sorusu gündeme gelir.

\subsection{Bakıș Açısı}

Savaş fotoğraflarındaki başarı, genelde karar anı, duruş noktası ve bakış açısının uyumlu şekilde bir araya gelmesiyle oluşur. Yine de hazır karar anının en fazla yer aldığı sahneler, her şeye rağmen genellikle bunlar arasından çıkar. Bir kere bu fotoğraflarda söz konusu olan duruş noktası, can güvenliği nedeniyle, foto muhabirinin özgür seçimine bağlı değildir. Dolayısıyla burada kayda geçecek görüntü, fotoğrafçının ayağına gelmekle kalmayıp, ayrıca bakış açısına da elverişli konumda olmalıdır (Capa, 2020, s. 121).

Bağdat'ta patlama sonrasını belgeleyen bu örnekte, karar anı konusunda sıkıntı çekilmediğini söylemek mümkün olsa bile, aynı şeyi duruş noktası için ileri sürmekte zorlanırız. Savaş koşullarında duruş noktasıına en uygun yer, saklanmaya elverişli olandır. Duyarlı levha, bu ortamda kör kurşuna karşı yeterli önlemi alanın kayıt defteridir. Buna göre, bir bütün olarak ele alındığ 1 zaman, savaşta hayatta kalma dürtüsünün yol açtığ 1 gizlenme ihtiyacı, özünde belgelemeyi yönlendiren iç mantığın dayatmasıdır. Nitekim biraz kurcalayınca hemen fark edildiği üzere, her belgeleme, özünde gizli kalmaya aday bir şeyin örtüsünü aralayarak, o ana kadar saklı duran bir gerçeği kanıtlama etkinliğidir. Öyle ki, fotoğraf söz konusu olduğunda, bu belirlemenin sadece gelip geçici herhangi bir olayı değil, doğadan portreye kadar her şeyi kapsadığını çekinmeden söyleyebiliriz. Ayrıca sabit hale gelen her görüntü, bir bakıma kendiliğinden zamansal var oluşun kaydı olduğuna göre, duyarlı levhada yer alan ne varsa, hemen hepsinin zaten gizlenme potansiyeliyle orada yer aldığını söylemek yanlış sayılmaz.

Bu arada tekrar Bağdat'taki savaşın kaydına dönmeden önce, geleneksel göz veya karın hizasındaki bakış hattının sorgulanmasıyla, fotoğraf tarihine Rodchenko usulü olarak geçen duruş noktası üzerinde kısaca durmaya çalışalım. Rodchenko, önemsiz birkaç istisnayı bir yana bıraktığımızda, resim tarihinde karşımıza çıkan tüm örneklerin karın yahut göz hizasındaki bakış hattından yapıldığını söyleyip, bunun insanoğlunun görsel alg1 ve düşünce dünyası için büyük bir tehlike olduğu konusunda 1srarla çevresini uyarıyordu: Günümüzde yaya olarak sokakta bulunan biri, tüm binaları aşağıdan yukarıya doğru görür. Yoldan geçen araba ve insanlara yukarı kattaki pencereden bakıldığı zaman ise tersine dönmüştür bu; ve böylece klasik karın hizasından görünüm dönüşüme uğramıştır artık (Kemp, 1978, s. 57). Burada söz konusu olan dönüşümün uygulamadaki karşılığı ise Giotto sonrası perspektifin sorgulanmaya başlamasıdır. Ortaçağ resimlerinde İsa'yı havarilerden, havarileri de sıradan ölümlülerden daha büyük temsil etmek mantıklıydı, çünkü "büyük" ile "küçük" algısal küçülme etkisi tarafından değil, dinsel öneme göre belirleniyordu. Giotto di Bondone ile birlikte "büyük" ile "küçük”ün boyutlarının mutlak anlamda değil, optik algıya göre düzenlenmeye başlamıştı. Başka bir deyişle o güne kadar Rönesans’tan itibaren ufuk çizgisini kerterez alan göz, konuyu başka bir açıdan görebileceğini fark etmiştir.

Görünürde patlamanın yol açtığı yıkımı belgeleyen bu örnek, savaş fotoğrafı bağlamında, çok sayıda kuraldışı tavırla doludur. Karar anından başlayalım: Buradaki karar zamansal olandan çok mekânla ilgilidir; üstelik savaş fotoğraflarında gündeme gelen gizlenme alışkanlığından ziyade, düzenlemedeki görsel duyarlığa ilişkin estetik kaygıyla. Bir başka deyişle, fotoğrafı çeken kişi, burada birbirine eklenen zincirleme anlar arasında en doğru olanı seçme gibi bir sorunla karşı karşıya gelmemiştir. Üstte kayda geçtiğinin 
farkında olan adamın rahatça poz vermesi, bu konuda hiçbir kuşkuya yer bırakmıyor. Öte yandan üst ile arkanın satıh etkisini koruyan dipyüzeyde örtüşme eğilimi, bu figürün duruşunu, bize daha etkili bir biçimde sunuyor hayal gücünün eşiğindeki bir figürün masalımsı varlığı. Kareye girecek olan sahne, orada öylece kaydedilmeye hazır beklerken, doğal olarak, foto muhabirinin duracağ 1 yeri dilediği gibi seçimi de bundan payına düşeni almıştır; bu ise karar anında zamanın baskısı olmadığını göstermektedir.

Bu örnekte asıl yadırgadığımız şey, duruş noktası ile bakış açısının yol açtığı birliktelikte ortaya çıkmaktadır. Muhabirin bastığı zemin bulmacadan farksızdır: Tek başına deliğe baktığımız zaman göz hizasını koruyarak yerde, bunun dışında kalanı dikkate alınca da kırk beş derecelik bakış açısıyla yukarıda duran birini görürüz. İki yanı duvarla çevrili yola gelince, burası ilk bakışta arkaya doğru daralarak düzenlemeyi yönlendirmeye aday bir perspektif yanılsamasına yol açmasına karşın, fotoğrafın gerekçesini kanıtlayan delik buna direniyor. Öte yandan, bu deliği, perspektifi doğrulamak üzere, ileriye doğru karşıdan değil, yukarıdan aşağıya doğru görme mecburiyetinde olmak, duruş noktası ile bakış açısının cilvesidir. Her ikisi de gerçeği gösteriyor, ama olabildiği kadar belirsiz bir şekilde. Oysa bakmaya devam edince hemen görüldüğü üzere, sağdaki duvarın arkaya doğru hızla küçülüp belirsizleşen yapıtaşları, perspektifin açıkça vurgulanmasıyla, deliği nereden gördüğümüz konusunda hiçbir kuşkuya zaten yer bırakmıyor.

Küçük görünenin büyükmüş gibi, büyük görünenin de küçükmüş gibi sunulduğu bir uzay, "geometral”'in partes extra partes bölümlenmesine indirgenemeyen bir uzaydır. Böyle bir uzayda perspektif bir uzlaşım değil, dramatik anlamda, tedirginliği, hareketi, krizi işin içine sokan bir eylemdir (Partes extra partes, şeylerin yan yana, birbirinin ardında durması, ancak aralarında bağlantı olmamasını, yalnızca dışsal bağımsız mevcudiyete sahip olmalarını anlatan terimdir). (Bonitzer, 2006, s. 153).

Yine izleyiciyi kararsızlığa sürükleyen sorulardan biri de isabet alan bu deliğin nereye ait olduğu konusunda karşımıza çıkıyor. Adamın bulunduğu zemin yol gibi görünmesine karşın, içinden eğilip bükülmüş demirlerin fırladığ 1 delik, ilk elde burasının duvar oluğu konusunda yeterli ipucu veriyor; ama sıra terasın zemini mi, yoksa alttaki katın tavanı mı sorusuna gelince zorlanmaya başliyoruz. Sağdaki duvar, bu bölümün sokakla aynı seviyede, yani yol olduğu izlenimi verirken ne karşı tarafta duran pencere ne de delikten görünen aşağ1sı, daha doğrusu bu deliğin solundan aşağı doğru inen duvar bunu doğruluyor. Diğer taraftan, hiç şüphe yok ki, bu fotoğrafla ilgili daha birçok şey sıralanabilir, ama şu gerçeği unutmamak gerekiyor: Duruş noktası ve bakış açısının desteğini alarak benzerleri arasında açık ara ön plana çıkan her karar anına, henüz adını koyamadığımız bir başka şey daha eşlik eder - şimdilik kaydıyla da olsa, pekâlâ talih kuşu diyebiliriz buna.

Nitekim bir an için bu sahnenin yerden ve göz hizasındaki bakış hattından kaydedildiğini varsaymamız halinde ne ile karşılaşacağımızı tahmin etmek hiç de zor değildir. Buna göre yıkımın gücünü belgeleyen deliğin etkisini yitirmesi, foto muhabiri için büyük önem taşımakla beraber, çerçevelenen sahnenin üst kısmı da burada aynı ölçüde kayda değer bir niteliktedir. Tablası yere düşmüş masanın çıplak iskeleti ve belli bir küme etrafında zemine gelişigüzel yayılmış taş parçaları vb. sanki Joseph Beuys'un 1983-5 arasında yaptı̆̆ "Yirminci Yüzyılın Sonu" isimli işini çağrıştıran sahne tasarımıyla Beckett' in herhangi bir oyununa model teşkil etmektedir. Ama bu sahnede en kışkırtıcı şey, sol üst köşeden deliğe doğru akan beyaz lekenin bir tür yabancılaştırma öğesi olarak fotoğrafa girmiş olmasıdır; katı konturları ile dış dünyadaki karşılığı ile buluşmak için firsat kollayan amorph bir iz.

\subsection{Duruş Noktası}

Farklı açıdan talih kuşunun konduğu bir başka fotoğraf da Mustafa Bilge Satkın imzalı Köprüden Bakış. Bu örnekte belki izleyicinin alması gereken özel bir mesaj yok; ama kayda geçtiği sürece her gösterge daha fazla yoruma açık hale gelir (Görsel 4). Bir sanat eserinin kayıt aracılığıyla sakladığı şey, yorumlarıyla buluşma olasılığını zamana yaymaktır. Dolayısıyla söz konusu örnekte içeriğe ilişkin görünürdeki kayıtsızlığın aslında karşıtını kışkırttığını söylemek yanlış sayılmaz. Sonuçta animal symbolicum olarak, insanoğlu her ize bir anlam atfetmeye şartlanmıştır. Nitekim bu örnekte de aynı şeye tanık oluyoruz; biçimsel kaygıyla çekildiği belli olan fotoğraf, tam da bu yüzden biçim aracılığıyla içeriğini arıyor. Burada, hazır sırası gelmişken, Nietzsche'yi anımsamakta fayda var: "Sanatçı, sanatçı olmayanın biçim dediği şeyi içerik olarak algılayan kişidir” (Nietzsche, 1966, s. 48). 


\section{Görsel 4}

Köprüden Bakış

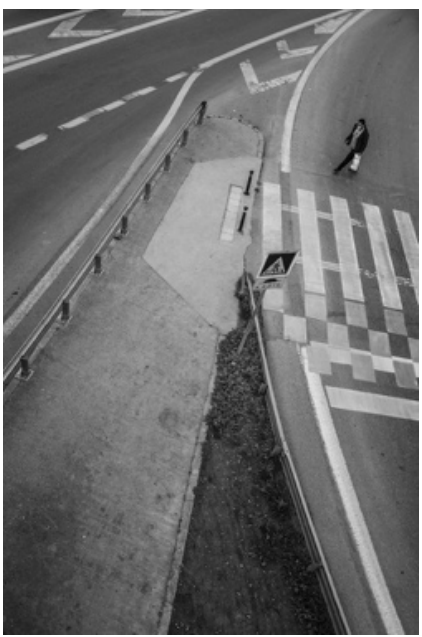

(Satkın, 2020).

Köprüden Bakış, bu bağlamda ilginç bir örnek teşkil ediyor: Mustafa Bilge Satkın, belli ki, kayda en uygun düştüğüne inandığ kareyi bulduğunda, öyle fazla beklemeden hemen deklanşöre basmış. Otoyoldaki beyaz şeritler, uyarı işaretleri, korkuluklar vb. bunların soyut bir düzenleme iradesinden payına düşeni alırcasına dağılımı, sonuçta duruş noktasının armağanı olarak fotoğrafa ekleniyor. Ancak, buna geçmeden evvel, fotoğrafa tesadüfen girdiğini son anda girdiğini fark ettiğimiz maskeli adamdan başlayalım. Elindeki dolu poşetten alışveriş sonrası evine döndüğü belli olan bu adam, geçmek zorunda kaldığı tehlikeli otoyola bakınca, kentin varoşunda yaşayan biri. Ama bu kadarı bile, bize fotoğrafın henüz hava kararmadan akşamüstü çekildiğini, adamı evde bekleyen birileri olduğunu ve Covid-19'a henüz çare bulunmadığını gösteriyor. Aslında böylesine geniş bir alanda tek başına görünen bu adam yalnız değil, itilmiş sadece. Bu yüzden, sözde uygarlığın otoyoldaki işaretlere dağılarak asfalttan önce göz boyaması ile söz konusu adamın eve dönüşü, trajik bir çelişkinin belgesi burada. Hiç şüphe yok ki, bu fotoğrafın kaydı ardında böyle bir niyet aramak, aşırı zorlama olur; fakat şunu unutmayalım: İlk bakışta anlamsız görünen sabit bir izi dahi yorumobur'a çevirip, kıyasıya hesaplaşmaya girişmek, âdemoğlunun değişmeyen takıntıları arasında nerdeyse ilk sırayı alır. Yine arkaya doğru daralan otoyol ile güçlü perspektif, resme bakan kişiyi vurgularcasına, düzenlemedeki ileriye doğru yol alacak muhayyel figürü de sırtı bize dönük şekilde canlandırıyor. Öte yandan bu figürün otoyolda izleyeceği yön, yolun her iki tarafındaki ters istikameti gösteren işaretler ile izleyiciyi tuhaf bir şekilde hazırlıksız yakalıyor sanki - ters yöndeyiz! Bu belirleme ise, doğal olarak, gerekçesini açıklamakta zorlandığımız bir şeyler söylemeye itiyor bizi: en azından, eve dönen adam tekinsiz bir yerden geçmek zorunda. Daha yakın zamana kadar Abdülhak Şinası Hisar'ın deyişiyle "köylü yollar"'n sakini olan bu adam, şimdi soyut bir düzenlemeden farksız işaretler arasında "kurallı yollar’la boğuşuyor. Dahası, hiçbir canlının yer almadığı otoyolda, söz konusu işaretler büsbütün ürkütücü.

Bu aşamada, yorum adına spekülasyona bulaşmadan, kısaca şu sorunun yanıtını bulmaya çalışalım: Mustafa Bilge Satkın, bu fotoğrafı çekerken o adamın varlığını dikkate aldı mı ya da karar anı için herhangi birinin oradan geçmesini özellikle bekledi mi? Buna olumlu yanıt vermek çok güç, hatta imkânsız, ama emin olduğumuz bir şey var: bulunulan yerden otoyolun görünümü, asfalta aktarılmış soyut düzenleme olarak, orada kayda hazır bekliyordu; ve Satkın için önemli olan da öncelikle bunun kayda geçmesiydi. Buna göre yoldan geçmekte olan adamı bir yana bıraktığımızda, karar anını zaman ile sınırlayacak hiçbir şey yoktu bu kayıt sürecinde; çünkü burada duruş noktasıyla buluşan bakış hattında zamanın akışı, herhangi bir müdahaleye gerek kalmaksızın, kendiliğinden durmuştur zaten. Peki, bu fotoğrafta çok sayıda ve hareket halinde insan olsaydı ne olurdu? Bakış hattı duruş noktasına göre yukarıdan aşağıya doğru olduğu sürece, belki yorum değişirdi, üstelik hiç zorlanmadan, ama bu bakış hattının göz hizasında kalması halinde, her şeye sıfırdan başlamaktan öte geriye bir çıkış yolu kalmazdı! Aslında Köprüden Bakış da tıpkı Bağdat’taki saldırıyı belgeleyen fotoğraf gibi, sözü uzatmaktan yana değil: Duruş noktası, her fotoğrafın görünmeyen altlı̆̆ıdır.

\section{Sonuç}

Fotoğraf çekme hareketi bir dizi sıçramadan meydana gelir; fotoğrafçı bu sıçramalar sayesinde çeşitli uzayzaman kategorilerinin engellerini aşar. Böyle bir engelle (örneğin yakın ve toplu görüntü arasındaki sınırla) karşılaştığında duraksar, aygıtı nasıl ayarlayacağına karar vermesi gerekmektedir. Fotoğrafçı ne zaman bir engelle karşılaşsa, "nesne" üzerinde yoğunlaşmış belli bir bakış açısına sahip olduğunu ve aygıtının bundan 
farklı olan sayısız bakış açısı sunduğunu kabul eder. "Nesnesine" yönelik bakış açılarının çok sayıda ve eşdeğerli olduğunu görür. Meselenin mükemel bakış açısını benimsemek değil, olabildiğince çok bakış açısını gerçekleştirmek olduğunu anlar. Yani seçimi niteliksel değil nicelikseldir (Flusser, 2020, s. 51-52)

Araştırma sonucunda fotoğraf karesine yerleştirilen konunun kendi öznelliğini taşıyabilmesi için, içerdiği biçimlerin ilişkilerinin kesinlikle açık ve yerinde olması gerektiği görülmektedir. Şüphesiz makine, karşısına çıkan görüntü ile göz göze gelecek şekilde boşluk içinde konuya göre yerleştirilmelidir ve işte bu noktada duruş noktası önem kazanmaktadır. Bağdat'ta Patlama ve Köprüden Bakış iki farklı senaryoyu yansıtırken vizörün arkasındaki gözler konuya ortak bir açıdan bakmakta ve "duruş noktası" ile birlikte yorumun nasıl değiştiğini göstermektedir. Fotoğraftaki iki figür ile Yıkıntılar Arasında Yaşlı Kadın fotoğrafında olduğu gibi göz hizasından karşılaşılmış olsa, kaybolan dipyüzey ile birlikte anlamın da değişeceği aşikârdır.

Henri Cartier Bresson'a göre fotoğraf, gerçekliğin içindeki yüzeylerin, çizgilerin ya da değerlerin ritmini keşfeder. Göz konuyu ayıklar ve makinenin görevi, gözün verdiği kararı filme aktarmaktır. Bir fotograf bütünlüğü içinde görülür, kompozisyon görsel ögelerin organik birlikteliği, eş zamanlı bir birlik oluşturmuş tablo gibidir. Bu birliktelik boş yere değil, bir gereklilik sonucu oluşur ve arka plan biçimden ayrılamaz (Cartier Bresson, 2006, s. 22-23). Dolayısı ile fotoğrafçı için özne ile birlikte arka plan olarak seçtiği görüntünün de olanaklarını keşfetmeye çalışarak konuya için en uygun olabilecek duruş noktasını arar.

Fotoğrafın kendine özgü estetik değeri, hareketin yakalanmasını esas alır: kabul etmek gerekir ki fotoğraf anı yakalarken aynı zamanda yaşama dair bir sezgi oluşturur. Gözümüz ancak fotoğrafın hareketin içinde de anlamlı dengeyi hissetmesi gerekir, gözümüz ara vermeksizin ölçer ve değerlendirir. "Duruş noktası" ile belirlenen kompozisyon "karar anı" ile film yüzeyinde sabitlenir. Fotoğrafın doğasına özgü amorf unsurlar kayda girdiğinde anlam genişler ve yorum bundan payına düşeni alır. Fotoğraf için kompozisyon her zaman bir önceliktir, fakat 1ş1kla beraber belirginleşen görüntü sezgisel bir şekilde sabitlenmelidir. Fotografik görüntü, ilişkilerin değişken olduğu çok kısa anların kayıtlarından doğar. Her türlü olasılığın kesiştiği bu noktadan itibaren fotoğraf artık düşünsel bir malzemeye dönüşür. 


\section{Kaynakça}

Bonitzer, P. (2006). Kör alan ve dekadrajlar. İ. Yaşar (Çev.). Metis Yayınları.

Capa, R. (1943a). Agrigento harabeleri arasında yaşlı kadın [Fotoğraf]. Collection of the Hungarian National Museum, International Center of Photography, Magnum, Hungary. https://www.arte.it/foto/la-liberazione-dirobert-capa-617/5

Capa, R. (1943b). Savaş insanlık dışıdır [Fotoğraf]. Collection of the Hungarian National Museum, International Center of Photography, Magnum, Hungary. https://tr.pinterest.com/pin/257690409914486103/

Capa, R. (2020). Hafifflu. A. Altuntaş (Çev.). Espas Kuram Sanat Yayınları.

Cartier Bresson, H. (2006). Karar anı. İ. Maga (Çev.). YGS Yayınları.

Duane, M. (1976). Real dreams: Photostories, Thames \& Hudson.

Flusser, V. (2020). Bir fotoğraffelsefesine doğru. A. Yı1maz (Çev.). Espas Yayınları.

Kemp, W. (1978). Foto-essays. Schirmer/Mosel.

Nietzsche, F. (1966). Seçilmiş düşünceler. S. Tiryakioğlu (Çev.). Varlık Yayınları.

Reuters Photographer. (2004). Băgdat'ta patlama [Fotoğraf]. https://www.alamy.com/an-iraqi-man-stands-nearthe-collapsed-ceiling-of-his-house-following-an-overnight-blast-in-western-baghdad-december-29-2004-apowerful-blast-destroyed-a-house-in-western-baghdad-during-an-overnight-police-raid-flattening-severalnearby-buildings-and-killing-at-least-28-people-including-seven-policemen-police-said-on-wednesdayreutersfaleh-kheiber-hhabp-image380920845.html

Satkın, M. B. (2020). Köprüden bakış. Mustafa Bilge Satkın kişisel arşivi.

Szarkowski, J. (2002). William Eggleston's guide. The Museum of Modern Art. 